\title{
Influence of Interest Rate on Industrial Output in Nigeria
}

\author{
Chioma Chidinma George-Anokwuru ${ }^{1} \&$ Itoro Bosco $^{1}$ \\ ${ }^{1}$ Economics Department, Faculty of Social Sciences, University of Port Harcourt, Rivers State, Nigeria \\ Correspondence: Chioma Chidinma George-Anokwuru, Economics Department, Faculty of Social Sciences, \\ University of Port Harcourt, Rivers State, Nigeria. E-mail: chiomanwoga@yahoo.com, bosco3m@gmail.com
}

Received: May 13, 2020; Accepted: May 31, 2020; Published: June 2, 2020

\begin{abstract}
The study examined the effect of interest rate on industrial sector in Nigeria from 1980 to 2018. The data for the study were sourced from Central Bank of Nigeria (CBN) statistical bulletin and Autoregressive Distributed Lag model was used as the main analytical tool. The ARDL Bounds test revealed the existence of long run relationship among the variables. The result further revealed the existence of a positive relationship between interest rate and industrial output both in the long run and short run. The rate of inflation was negatively related to industrial output but the relationship was not significant in both the short run and the long run. The number of labour force affected the productivity of industry thereby increasing its output in both the short run and the long run. Gross investment has a positive relationship with industrial output but the relationship was not significant. Lastly, foreign direct investment was not significant in affecting industrial output in the short run but it was positive and significant in affecting industrial output in the long run. The study concluded that interest rate has the ability to influence industry output in Nigeria. Therefore, the study recommended among others that the apex monetary institution - the Central Bank of Nigeria should ensure that the rate of interest that will encourage investors to borrow in order to start to do businesses or to expand their businesses. This will increase industry output and in turn support economic growth in Nigeria.
\end{abstract}

Keywords: interest rate, industrial output, ARDL and Nigeria

\section{Introduction}

Financial economists have long debated the relative merits of bank/market based financial systems for over a century. Many authors stress the advantages that banks have over market in financing the expansion of the existing firm, in promoting the establishment of new firms and inefficiently allocating capital. The effectiveness of an economy depends to a large extent on the policy outlook of its monetary authorities (Gbosi, 2015). This will reflect on the structure of rates at which they give to investors. The central interest of this study will lie with the rate at which financial institutions lend to borrowers of funds. This rate determines the volume of financial resources an investor (borrower) can access at a defined point in time, and it is technically defined as interest rates.

Interest rates are the rewards a borrower (debtor) receives from a lender (creditor) for the use of money for a period, and they are usually expressed in percentage terms, for example, $7.0 \%$, in order to make them comparable. Interest rate is the payment made for the use of credit by borrowers and return for parting with liquidity by lenders (CBN, 1997). Therefore, low interest rate serves as incentive to investment. Entrepreneurs base their demand for loanable funds for purposes of investment on the marginal efficiency of capital. The higher the productivity of new capital good financed from the loan, the greater the willingness to borrow and vice versa. It is the cost of borrowing funds.

Interest rate performs several important functions in that they influence a broad range of economic decision. As a reward for storing up financial assets and letting go current consumption, interest rate is a way of encouraging people to save. Also, the level of interest rate, rate of return on financial assets, changes in exchange rate, determine the allocation of public wealth among financial assets.

On the other hand, as cost of capital, interest rate affects the demand for and supply of credit (loanable funds). Changes in the rate of interest will influence investment for expansion, machinery and equipment. Interest rate makes it easier for funds to be mobilized from surplus spending units (savers) to deficit spending units (investors) of the economy for efficient utilization of such funds for the enhancement and growth of industrial output. Interest rate is a vital component of the financial market and a crucial tool of monetary policy. Interest rate is an important economic price. This is because whether seen from the point of view of cost of capital or from the perspective of opportunity cost of funds, interest rate has fundamental implications for the economy. By either influencing the 
cost of capital or availability of credit, by increasing savings, it is known to determine the level of investment in an economy. As the positive relationship between investment and economic development is well established, it therefore becomes expedient for any economy that wishes to grow to pay proper attention to changes in interest rate. Nigeria being a country in dire need of development cannot overlook the important role interest rate could play in this direction.

The industrial productivity is a prerequisite for the growth of the economy at large and it belongs to the deficit spending units. These deficit spending units depends basically in borrowed funds from the surplus spending units for investment. The benefits of industrial productivity can be seen in all aspects of life from the range of consumer goods available, to the efficiency of transportation systems, indeed about $74 \%$ of the world's industrial output takes place in the developed world. Industrial growth enables a country to fully utilize its factor endowments and depend less on external contributions for its growth and sustenance. The manufacturing sector in any economy is attributed to be the engine of growth and the vital source of sustainable growth and development. It is the steering wheel of the transformation of an under-developed economy to an advanced economy.

By the mid-20th century, Nigeria's industrial sector was dominated by agricultural production. However, the 1970's oil boom changed the entire equation. The oil sector became the main-stay of the economy. As the foreign currency earned by the Nigerian government increase, the government neglected the agricultural and non-oil industrial sectors. Massive migration from villages to oil producing cities resulted in large unemployment and low standard of living. The major Nigeria industrial sectors include the mining sector where oil and natural gas is a sub-sector. According to the 2005 figures, it accounts for more than $90 \%$ of the annual national production and generates more than $80 \%$ of the government revenues. The country produces 2.5 million barrel per day (NNPC, 2016). Although major reforms have been undertaken to liberalize the country's economy, the oil sector is still under the scrutiny of the government.

Other major industrial sectors in Nigeria include the telecommunication of which the Nigeria Communication Commission has the responsibility to develop mobile phone. In Nigeria, the industrial sector has been hindered by high interest rates, particularly, the interest rate spread. It alleged that this rate is partly responsible for high cost of production in the industrial sector (Adebiyi, 2001). Besides an observed direct impact, most studies also acknowledge an indirect impact on growth and industrial development.

The government laid down priorities from time to time initiated measures to achieve industrialization such measures includes reconstructing damaged industrial capacities, the promotion of expansion of the intermediate and capital goods industries in order to raise the contribution of value added in the industrial sector and the promotion for rapid industrial development. In addition, the government in a bid to eliminate stabilizes interest rates have through the monetary authorities changed the structure of interest rate to contract or expand the economy. The use of changing interest rates to thinker the problem of under-utilization of industrial sector in order to expand domestic production, encourage and prioritize exports over imports have to a large extent yielded little. To this end, this study focuses on examining the impact of interest rate on the industrial sector in Nigeria within the review period of 1980-2016.

The role of interest rates in the efficient allocation of resources and economic development of the Nigerian industrial sector cannot be underestimated. The volatility in interest rate over the years has a problem to this sector. Therefore, given the various policies and efforts made towards a reduction in interest rate charged or borrowed funds for investment, the industrial sector in Nigeria have performed unimpressively towards meeting up its target of creating employment opportunity, building high technology etc. this calls for a rapid look into the effects of interest rate on the industrial sector in Nigeria. The objective of the study is to examine the effect of interest rate on industrial sector in Nigeria.

\section{Literature Review}

The Classical Theory: This theory posits that the rate of interest is determined by the interplay of the forces of supply and demand of capital by businessmen and household respectively. The supply of capital is governed by the time preference and demand for capital by the expected productivity of capital (Anyanwu, 1990).

The Keynesian Liquidity Preference Theory of Interest Rate: Keynes defined the rate of interest as the reward for parting with liquidity for the specific period. He did not accept the view that savings and borrowing must always balance, nor that is this balance arrived at through the mechanism of interest rate. Instead Keynes argued that if interest rates were low and expected to go up, people will hold money rather than invest it and so savings and borrowing will not be equal. In explaining interest rates the liquidity preference theory argues that interest rate levels are set by the supply and demand for holding money speculations. The supply of money refers to the total quantity of money in the country for all purposes at any time and is considered to be fixed by the monetary 
authorities. Thus, the supply curve of money is perfectly inelastic. Keynes therefore identified three motives for holding liquid cash namely, (i) Transaction motive (ii) precautionary motive (iii) speculative motive.

The Loanable Funds Theory: This theory determines the interest rate by the interaction of demand for and supply of loanable funds or credit. It involves the linking of the interest rate with dissaving, investment and boarding of funds sourced from government, businessmen and consumers on the demand side with saving, dishoarding and bank money on the supply side from private individuals and corporate bodies. Hansan asserted that the loanable funds theory like the Classical and Keynesian theories of interest is indefinite unless the income level is already known.

Modern Theory of Interest: The Hides-Hassan IS-LM model, it is evident that no single theory of interest rate is adequate and determinate. An adequate theory to determine interest rate must take into consideration both the real and monetary factors that influence the interest rate. Recall that $\mathrm{M}^{\mathrm{d}}=\mathrm{L}(\mathrm{r}, \mathrm{y})$, thus money demand is also a function of output $\mathrm{Y}$. where output rises, the money demand curve will thus rise and therefore the equilibrium level of interest rate (r) will also rise.

\section{Empirical Literature}

An investigation into the activities of the banking sub-sector in Nigeria over the review period shows that while lending rates have remained within the double digit bracket, private sector credit (a potential driver of economic activity) as a percentage of total credit declined from $27.04 \%$ in 1992 to about $0.15 \%$ by 2012 (CBN, 2012). The CBN (2012) also shows that interest rate on loans peaked at $36.09 \%$ in 1993 while rates paid on deposits significantly declined during the period, ebbing at 1.43\% in 2011. The period 2004-2012 saw deposit rates crash from $4.19 \%$ in 2004 to $1.43 \%$ in 2011 before it marginally increased to $1.70 \%$ in 2014 .

Empirical studies on the capacity of the reformed interest rate to promote the growth of the real sector, and by extension the growth of the entire economy, show mixed results. For instance, Ezeaku, Ibe, Ugwuanyi, Modebe and Agbaeze (2018) examined monetary policy transmission and industrial sector growth in Nigeria for the period 1981-2014 using Johansen cointegration and the Error Correction Model (ECM). The result revealed that that private sector credit, interest rate, and exchange rate channels have negative effects on real output growth, both in the long run and in the short run. The results further showed that, relatively, the degrees of the established effects are higher in the long run than in the short run.

Ozigbu (2018) analyzed the long-term implication of interest rate deregulation on the productivity of the industrial sector in Nigeria between 1987 and 2016 using Autoregressive Distributive Lag (ARDL) model. The Augmented Dickey-Fuller (ADF) stationarity test approach and ARDL based bounds test approach to cointegration were applied to test the null hypotheses of a unit root and no long run relationship respectively. It was found from the ADF tests results that the variables are fractionally integrated. The bounds test result also indicates that the variables are long run relationship.

Aiyedogbon and Anyanwu (2016) examined the macroeconomic determinants of industrial development in Nigeria between 1981 and 2013. The study included exchange rate, consumer price index, broad money supply, and interest rate among others in the model as determinants of industrial production index. The estimation technique adopted by the study is Ordinary Least Squares (OLS) and the result reveals that exchange rate, interest rate, and foreign direct investment impacted positively on industrial production index while consumer price index, broad money supply and credit to manufacturing sector impacted negatively on industrial sector performance. The study recommended for the determination of effective and efficient broad money supply capable of enhancing the availability of credit to the manufacturing sector and equally controls interest rate to stimulate investment.

Aghion, Farhi and Kharroubi (2015) investigated the role of counter-cyclical interest rate on growth of industrial sector. Panel data for cross-industry, cross-country was used to ascertain whether real short-term interest rates and industry level measures of financial constrain affect industrial growth. A multivariate regression model was adopted for the study and the findings reveal that the counter-cyclical real short-term interest rate has significant and positive effect on the average annual growth of the industrial labour productivity. It was evident from the results that the effects of the variables on the industrial growth are more significant in the period of recession than during expansion period.

Tomola, Adebisi and Olawole (2012) analyzed bank lending, economic growth and the performance of manufacturing in Nigeria. They find a significant impact of bank lending rate and manufacturing capacity utilization rate on manufacturing output in Nigeria. 
Charles (2012) investigated the performance of monetary policy on the manufacturing sub-sector in Nigeria. He finds a positive impact of money supply on manufacturing output. The study however, reveals that lending rate, corporate tax, inflation and exchange rate have negative impact on the performance of the sub-sector in Nigeria.

Obamuyi and Olorunfemi (2011) examined the implication of financial reforms and interest rate on economic growth in Nigeria. Data over the period 1970-2006 were analyzed using the co-integration and error correction analytical techniques. The result indicates that financial reform and interest rate have significant positive impact on economic growth. They recommend that government should embrace growth-enhancing reforms as well as monitor closely movements in interest rate.

Adofu, Abula, and Audu (2010) examined the effect of interest rate deregulation on agricultural sector productivity in Nigeria. Annual data over the period 1986-2005 were analyzed using the technique of the Ordinary Least Squares (OLS). They find a significant positive effect of interest rate on agricultural output during the period.

Obamuyi (2009) investigated the relationship between interest rate and economic growth in Nigeria using data over the period 1970-2006. Employing error correction analysis, he finds that lending rate exerts a significant negative impact on growth while deposit rate shows a significant positive effect on growth. The result also shows a significant negative impact of inflation on growth.

Odhiambo (2009) examined the effect of interest rate liberalization on economic growth in Zambia. Regression results show evidence of a strong support for positive impact of interest rate on financial deepening. He also finds that financial deepening granger-causes growth.

Okoye (2006) examined the effect the interest rate on productive activities in Nigeria using data on selected manufacturing industries. The study shows evidence of positive effect of interest on manufacturing output.

Adebiyi and Obasa (2004) examined the impact of interest rate policy on the financing of Nigerian manufacturing sub-sector using annual data for the period 1970-2002. They find that interest rate exerts a negative impact on the growth of the sub-sector in Nigeria.

Mohammed (1990) examined the effect of interest rate and other selected macroeconomic indicators on manufacturing operations in Nigeria using the co-integration and error correction models. He finds that interest rate and government deficit spending hamper the growth of the sector Nigeria.

A careful examination of the empirical literature revealed that there are differences in opinions and empirical findings. While some scholars including Okoye (2006) argued that interest rate influenced industrial sector positive, others including Charles (2012), Ezeaku, Ibe, Ugwuanyi, Modebe and Agbaeze (2018) argued that interest rate influenced industrial sector negatively. The divergence in opinions and empirical findings on the influence of interest rate on industrial output is of serious concern, especially in Nigeria. The above state of affairs raised a pertinent question: what is the relationship between interest rate and industrial output in Nigeria? An answer to this question was the major concern of this paper.

\section{Methodology}

The study used time series data sourced from Central Bank of Nigeria (CBN) Statistical Bulletin of various issues. The study employed Auto-regressive Distributed Lag (ARDL) technique to estimate the influence of interest rate and industrial output. This was important so as to ascertain the effects of the past values of industry output, the past and present values of interest rate, inflation rate, labour force, investment, and foreign direct investment. The short run dynamics of the Auto-regressive Distributed Lag model is specified thus:

$$
\begin{aligned}
& \operatorname{InINDPT}_{t}=\beta_{0}+\beta_{1} I N T R_{t}+\beta_{2} I N T R_{t-k}+\beta_{3} I N F_{t}+\beta_{4} I N F_{t-k}+\beta_{5} L A B_{t}+\beta_{6} L A B_{t-k}+\beta_{7} G F C F_{t}+ \\
& \beta_{8} G F C F_{t-k}+\beta_{9} F D I_{t}+\beta_{10} F D I_{t-k}+E C M_{t-k}+u_{t}
\end{aligned}
$$

The long run form of the Auto-regressive Distributed Lag model is specified thus:

$\operatorname{InINDPT}_{t}=\beta_{0}+\beta_{1} I N T R_{t}+\beta_{2} I N F_{t}+\beta_{3} L A B_{t}+\beta_{4} G F C F_{t}+\beta_{5} F D I_{t}+u$

Where, INDPT is industrial output, INR is interest rate, INF is inflation rate, LAB is labour force, GFCF is gross fixed capital formation, FDI is foreign direct investment, and $u$ is error term.

\section{F-Bounds Cointegration Test}

The F-bounds test is a technique of the Auto-regressive Distributed Lag (ADL) that ascertained if variables are cointegrated. This was adopted to ascertain the long run relationship between public infrastructure and industry value added.

Autocorrelation Test: The Durbin Watson test was used to test for the presence of autocorrelation in the model. 
Heteroscedasticity Test: The Breusch-Godfrey heteroscedasticity test was used to ascertain if the error variance of each observation is constant or not.

Normality Test: The Jacque-bera test was used to test if the variables in the model follow the normal distribution.

\section{Results and Discussion}

\section{Trend Analysis}

The trend analyses bother on the trends in industry and interest rate during the period under review. The trend in industry output is displayed in figure 1 and figure 2 .

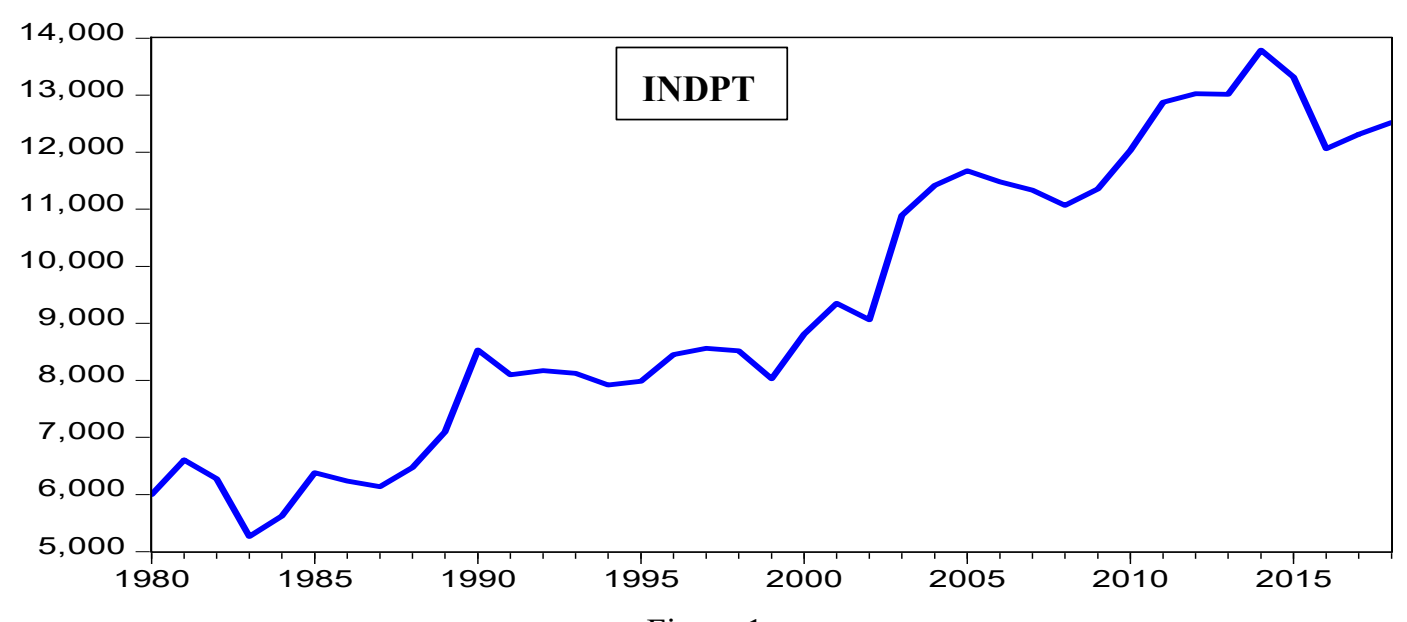

Figure 1.

The trend in industry output shows an upward fluctuation from 1980 to 2018. Industry output increased from $5,264.88$ billion naira in 1983 to $8,122.08$ billion naira in 1993. It further increased to 8,450.31 in the year 1996 . The increasing trend continued and reached peaked in 2018 (12,523.15 billion naira).

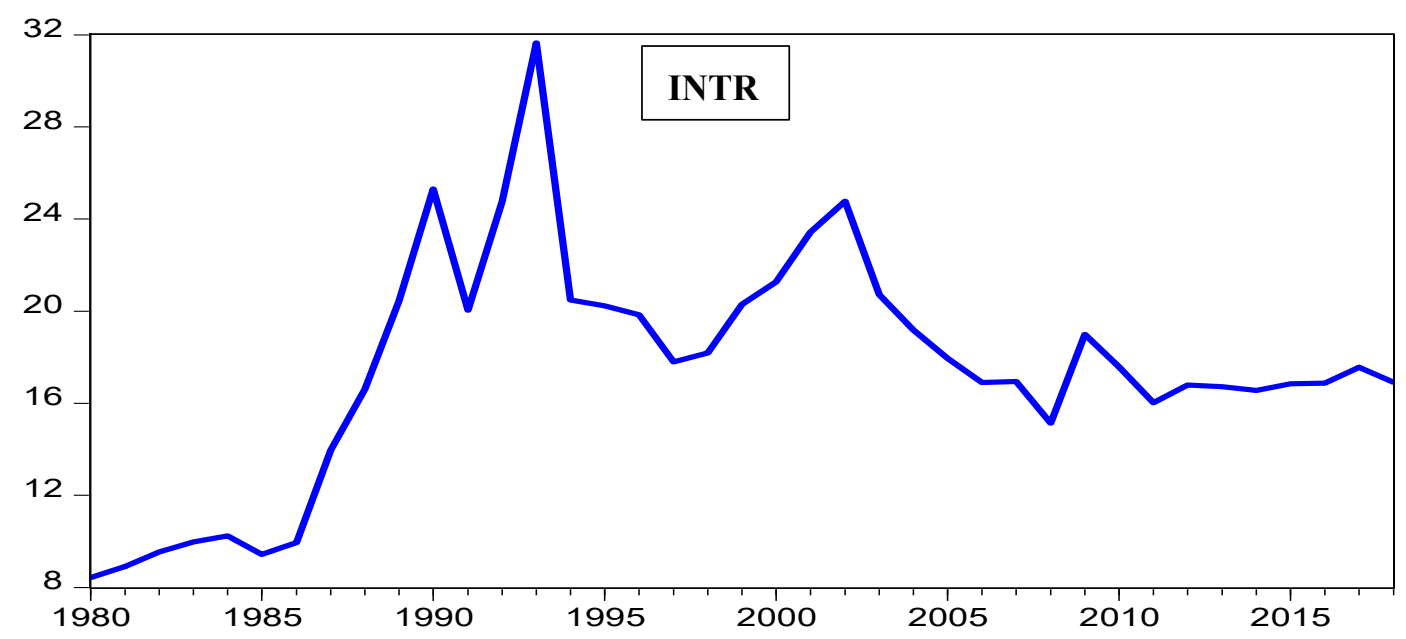

Figure 2.

Trend in interest rate shows that interest rate fluctuated upwards since 1980 and experienced a sharp decline in the 1991. It later increased and reached peak to $31.65 \%$ in 1993 . Since then, the interest rate has showed decreasing but stabilizing trend. Interest rate was $16.9 \%$ in 2018. 
Table 2. Diagnostics Test for Auto-regressive Distributed Lag Model

\begin{tabular}{lll}
\hline Diagnostics tests & & ADL Model \\
\hline \multicolumn{2}{c}{ Autocorrelation (Durbin Watson) } & 1.54 \\
& F-statistics & 0.8103 \\
& Prob. F-statistics & 0.5857 \\
& Obs*R-squared & 6.0425 \\
\cline { 2 - 3 } Heteroscedasticity (White) & Prob. Chi-Square & 0.5348 \\
& JB Statistic & 0.2613 \\
\cline { 2 - 3 } Normality (Jarque-Bera) & Probability & 0.8775 \\
& F-statistics & 3.26 \\
F-Bounds Test & Lower Bounds (5\%) & 2.39 \\
\cline { 2 - 3 } Adjusted R-Squared & Upper Bounds (5\%) & 3.38 \\
F-statistics & & 0.953 \\
Prob(F-statistics) & & 107.436 \\
\hline
\end{tabular}

Source: E-views 9.0

Table 2 shows the diagnostics tests for the Auto-regressive Distributed Lag model. The autocorrelation value of 1.54 implies there is no serial correlation in the error in the ADL model. The observed r-squared of the White's heteroscdasticity test shows that the variance is homoscedastic. Also, the Jarque-bera value of the normality test shows that the ADL model follows the normal distribution. The F statistics of the F-bounds test is 3.26. The F statistics of the F-bounds tests is greater than the lower and upper bounds at the 5\%. These show that the variables in the ADL model have long run relationship. The adjusted coefficient of determination is 0.953 . This implies that the $95.3 \%$ variation in industry output is explained by the variations in the independent variables. The p-value of the F-statistics shows that the ADL model was significant at the 5\% level of significance.

Table 3. ARDL Regression Results

\begin{tabular}{lllll}
\hline Short Run ARDL Regression Results & & & \\
\hline Variable & Coefficient & Std. Error & t-Statistic & Prob. \\
C & -0.955582 & 2.248434 & -0.424999 & 0.6739 \\
DLOG(INDPT(-1)) & -0.605861 & 0.158078 & -3.832670 & 0.0006 \\
D(INF) & -0.001149 & 0.000706 & -1.626461 & 0.1143 \\
D(INTR) & 0.004863 & 0.002551 & 1.906210 & 0.0662 \\
DLOG(LAB) & 0.279890 & 0.127131 & 2.201582 & 0.0355 \\
DLOG(GFCF) & 0.001270 & 0.058690 & 0.021636 & 0.9829 \\
DLOG(FDI) & 0.029542 & 0.017512 & 1.686925 & 0.1020 \\
DLOG(FDI(-1)) & 0.070726 & 0.025927 & 2.727905 & 0.0105 \\
CointEq(-1) & -0.605861 & 0.115694 & -5.236779 & 0.0000 \\
\hline Long Run ARDL Regression Results & & & \\
\hline Variable & Coefficient & Std. Error & t-Statistic & Prob. \\
INF & -0.001896 & 0.001193 & -1.589785 & 0.1224 \\
INTR & 0.008026 & 0.004381 & 1.832182 & 0.0769 \\
LOG(LAB) & 0.461970 & 0.139804 & 3.304399 & 0.0025 \\
LOG(GFCF) & 0.002096 & 0.096723 & 0.021669 & 0.9829 \\
LOG(FDI) & 0.116737 & 0.038252 & 3.051761 & 0.0047 \\
C & -1.577229 & 3.541955 & -0.445299 & 0.6593 \\
\hline
\end{tabular}

Source: E-views 9.0

The results show how interest rate affected industrial output in Nigeria during the period under review. The ECM coefficient, -0.60381 , shows the speed of adjustment to equilibrium is approximately $60.4 \%$. The ECM coefficient was significant at the $5 \%$ level of significance.

The coefficient of interest rate (0.004863) suggests that a positive relationship exist between interest rate and industrial output during the period under study. This implies that interest rate supported industry output in Nigeria in the short run. The p-value showed significant values at the $10 \%$ level. This provides sound reason to rely on the 
relationship between interest rate and industry output in Nigeria. More, so, the long run relationship between interest rate and industry output suggest that interest rate supported industrial output at the $10 \%$ level of significance. The implication of the positive relationship is that interest rate has encouraged business investment in Nigeria in both the short run and the long run. Evidence is shown in the trend in industry output where it has increased since 1980 .

Other variables that represented critical sectors in the model also affected industry output during the period under study. The results show that the rate of inflation was negatively related to interest rate but the relationship was not significant in both the short run and the long run. The number of labour force affected the productivity of industry thereby increasing its output in both the short run and the long run. Gross investment has a positive relationship with industrial output but the relationship was not significant. Lastly, foreign direct investment was not significant in affecting industrial output in the short run but it was positive and significant in affecting industrial output in the long run.

\section{Conclusion and Recommendations}

The study examined the effect of interest rate on industry output in Nigeria from 1980 to 2018. The study used the robust Autoregressive distributed lag model to estimate the model. Trend analysis showed that interest rate fluctuated upwards and downwards for the period under study. The study found that that interest rate supported industry output in Nigeria in the short run as well as in the long run. Other variables also affected industry output during the period under study. Based on the findings, it is recommended that:

1) The apex monetary institution, the Central Bank of Nigeria should ensure that the rate of interest should encourage investors to borrow to do business or to expand their businesses. This will increase industry output and in turn support economic growth.

2) Foreign investment should be encouraged to ensure industrial output is increased. Definitely, when the cost of funds is favourable for foreign investors, investment will increase.

3) The labour force should be developed to match with contemporary innovations in the various industries as their efforts ensure high productivity in the industrial sector.

\section{References}

Adebiyi M. A. (2001). Can High Real Interest Rate Promote Economic Growth Without Fueling Inflation in Nigeria. Journal of Economic and Social studies. Maiden Edition page 86-100.

Adebiyi, M. A., \& Obasa, B. B. (2004). Institutional Framework, interest rate policy and the financing of the Nigeria manufacturing sub-sector. Paper delivered at a forum for African macro-micro linkage, South Africa.

Adofu, I., Abula, M. \& Audu, S. I. (2010). Assessment of the effects of interest rate deregulation in enhancing agricultural productivity in Nigeria. Current Journal of Economic Theory, 2(2), 82-86.

Aghion, P., Farhi, E., \& Kharroubi, E. (2015). Liquidity and growth: the role of counter-cyclical interest rates. BIS Working Paper No. 489. Available at SSRN: https://ssrn.com/abstract=2564266

Aiyedogbon, J. O., \& Anyanwu, S. O. (2016). Macroeconomic Determinants of Industrial Development in Nigeria. Nile Journal of Business and Economics, 1(1), 37-46. https://doi.org/10.20321/nilejbe.v1i1.44

Alao, R. O. (2010). International Liquidity/Reserves and Foreign Exchange Rates. Review in Social Sciences, 8 , Adeyem: College of Education, Ondo, April (in press).

Ayodele, A. I., \& Falokun, G. (2003). The Nigerian Economy: Structure and Patter of Development. Jodad Publishers.

Central Bank of Nigeria Annual reports And Statements of Account, various issues.

Central Bank of Nigeria Statistical Bulletin. (2010). various issues.

Central Bank of Nigeria. (2012). Statistical Bulletin, Abuja: CBN, 23.

Charles, A. N. B. (2012). Investigating the performance of monetary policy on the Manufacturing sector in Nigeria. Arabian Journal of Business and Management Review, 2(1), 12-25. https://doi.org/10.12816/0002239

Chete, L. N., \& Adenkinju, A. (1996). Productivity Growth in Nigerian Manufacturing and its correlation with Trade Policy Regimes/Indices. Research for Development, vol. 11 number 1.

Chete, L. N., \& Adeoye, B. W. (2002). Human Capital and Economic Growth: The Nigerian Evidence. Paper presented at the $43^{\text {rd }}$ Annual Conference of NES, Sheraton Hotels, Lagos, August 6-8, 2002. 
Estimating A Monetary Policy Reaction function for the Central Bank of Nigeria. Retrieved December 23th, 2009. From http://www.africametrics.org

Ezeaku, H. C., Ibe, I. G., Ugwuanyi, U. B., Modebe, N. J., \& Agbaeze, E. K. (2018). Monetary Policy Transmission and Industrial Sector Growth: Empirical Evidence from Nigeria. SAGE Open April-June 2018, 1-12. https://doi.org/10.1177/215824401876936

Fabayo, D. A. (2003). Foreign Private Investment in Nigeria Manufacturing Sector. A paper presented at the $12^{\text {th }}$ Annual Conference of the Regional Research Units organized by the research department, CBN.

Falokun, G. O. (1998). Sources of Industrial Growth in Nigeria: A Factor Decomposition Approach. NISER Monograph Series Number 12, NISER, Ibadan.

Gbosi, A. N. (2015). Contemporary Macroeconomic Problems and Stabilization Policies (2 ${ }^{\text {nd }}$ edition). Spirit and Truth Publishers, Benin City, Nigeria.

Institutional Framework for Interest Rate and the Manufacturing Subsector. Retrieved from http://www.wikipedia.com

Kalu, I. E. (2001). Issues in Problems And Policies of Development. Development Economics, Mimeograph Series Number 1. Lagos, Techno Consult Ltd.

Niser. (2003). The Structure And Growth of the Economy in NISER Review of Nigerian Development, 2001/2002. NISER Publication.

Obamuyi, T. M. (2009). An investigation of the relationship between interest rates and economic growth in Nigeria, 1970-2006. Journal of Economic and International Finance, 1(4), 93-98.

Obamuyi, T. M., \& Olorunfemi, S. (2011). Financial reforms, interest rate behavior and economic growth in Nigeria. Journal of Applied Banking and Finance, 1(4), 39-55.

Ogunkola, E. O., \& Agah, Y. F. (2000). Nigeria And World Trading System. AERC/CREA Working Papers.

Okoye, L. U. (2006). The Impact of Interest Rate on Productive activities in Nigeria: A study of selected manufacturing industries in Nigeria. Unpublished Master of Business Administration Dissertation, Department of Banking and Finance, University of Nigeria, Nsukka.

Olofin, S., \& Iyaniwura, J. (1983). Analysis of Intersectoral Linkages in the Nigerian Economy. The Nigerian Journal of Economic and Social Studies, 25(2).

Olomola, A. S. (2009). Regional Integration in the Context of Socio Economic transformations In Africa: Issues And Approaches.

Ozigbu, J. C. (2018). Interest rate deregulation and dynamics of industrial sector's productivity in Nigeria. $\begin{array}{lllll}\text { International Journal of Innovation \& Development, } & 7(1), & 323-332 .\end{array}$ https://doi.org/10.24940/ijird/2018/v7/i1/AUG17105

Productivity in the Nigerian Manufacturing Industry". Retrieved from http://www.cenbank.org

Tomola, M. O., Adebisi, T. E., \& Olawale, F. K. (2012). Bank Lending, economic growth and the performance of the manufacturing sector in Nigeria. European Scientific Journal, 8(3), 19-34.

Towards Sustainable Interest Rate. Daily Trust Newspaper. Retrieved from http://www.allafrica.com

\section{Copyrights}

Copyright for this article is retained by the author(s), with first publication rights granted to the journal.

This is an open-access article distributed under the terms and conditions of the Creative Commons Attribution license (http://creativecommons.org/licenses/by/4.0/). 